\title{
Memória, testemunho e superação: história oral da anistia no Brasil*
}

\author{
Maria Paula Araujo**
}

Durante todo o ano de 2011 trabalhamos realizando entrevistas no Rio de Janeiro, São Paulo e Minas Gerais com o objetivo de constituir um acervo de depoimentos que pudesse contribuir para uma história oral da anistia no Brasil. O objetivo da pesquisa, que integramos junto com pesquisadores da Universidade Federal de Pernambuco e da Universidade Federal do Rio Grande do Sul, era realizar, em nível nacional, um amplo retrato do tema da anistia no Brasil, recolhendo depoimentos de pessoas que foram perseguidas pela ditadura militar; pessoas que foram anistiadas ou estão solicitando o benefício; familiares de mortos e desaparecidos; pessoas que se engajaram na luta pela anistia desde a década de 1970 e que participaram da criação e da ação política do Movimento Feminino pela Anistia e dos diversos Comitês Brasileiros pela Anistia (os CBAs que se espalharam pelo Brasil inteiro entre 1977 e 1979); militantes de movimentos sociais e políticos que lutaram contra o regime e militantes dos movimentos de direitos humanos. Esses depoimentos - recolhidos no Nordeste, no Sudeste e no Sul pelas equipes das três universidades mencionadas - foram gravados, filmados e transcritos, constituindo um amplo acervo sobre a história política recente do país.

Apresento aqui uma reflexão feita a partir da análise das entrevistas realizadas pela equipe do Rio de Janeiro. É uma versão resumida do texto que

* Este texto é uma versão reduzida do capítulo que escrevi para o livro Marcas da memória: história oral da anistia no Brasil (Araujo, 2012).

** Professora da Universidade Federal do Rio de Janeiro. 
eu escrevi para integrar o livro Marcas da memória: história oral da anistia no Brasil, produto da pesquisa realizada ainda a ser lançado. O trabalho de pesquisa - a coleta, o tratamento e a análise dos depoimentos - nos propiciou uma reflexão sobre alguns aspectos teóricos e metodológicos da história oral, tais como a articulação entre a memória e a retórica e a potencialidade do método biográfico. Além disso, a pesquisa trouxe à tona questões importantes sobre a memória do período repressivo: as disputas pela memória e a pluralidade de visões e de experiências. Enfim, no andamento de nossa pesquisa, constatamos que é possível construir uma narrativa histórica sobre a ditadura militar no Brasil a partir do tema da anistia, enfocando, principalmente, as múltiplas histórias de vida de cidadãos e cidadãs que foram atingidos pela repressão ou que lutaram contra ela.

\section{O direito à memória e à verdade na justiça de transição: a importância do testemunho}

Em nosso mundo contemporâneo, nas últimas décadas, inúmeras sociedades viveram transições políticas importantes: passaram de regimes ditatoriais e arbitrários para regimes democráticos. Em todos esses casos uma questão se colocou para a sociedade e para o Estado, logo após (e, muitas vezes, durante) o processo de consolidação democrática: o que fazer com a herança autoritária? Como olhar para esse passado, enquadrá-lo aos novos tempos, tratar as feridas, suprimir o legado da violência? O Estado deve escolher como proceder: apura crimes e responsabilidades? Pune culpados? Anistia crimes políticos? Repara moral e materialmente os danos causados? Reintegra antigos excluídos? Desmantela o aparato repressivo? Revela e divulga os fatos? Todas essas questões dizem respeito a procedimentos jurídicos e políticos que acompanham um processo de transição democrática. Esses procedimentos revelam como o Estado e a sociedade lidam com seu passado autoritário e compõe o que se convencionou chamar de "justiça de transição". Esse conceito tem sido discutido, nos últimos anos, por militantes e organizações de direitos humanos constituindo uma rede internacional que acompanha, debate e interfere em diferentes casos. Cada país adota diferentes medidas de "justiça de transição" - de acordo com a sua história, sua cultura política e a correlação de forças da época da transição. A justiça de transição implica algumas questões: direito à memória, responsabilização dos perpetradores e 
promoção de justiça, reparação das vítimas, reconciliação nacional. São fundamentalmente esses elementos que se articularão, em cada país, em função de suas circunstâncias conjunturais e estruturais (Brito, 2002). Mas em todos esses países - por mais diferentes que sejam os processos - um elemento tem se afigurado como fundamental: a palavra. Revelar os fatos, tornar pública as violações, denunciar as arbitrariedades, nomear responsáveis, resgatar a memória de lutas e resistências, tudo isso tem tido enorme papel simbólico e político na construção de um novo pacto nas sociedades pós-conflitos.

Argentina e África do Sul têm se constituído como dois paradigmas diferenciados, dois modelos distintos de justiça de transição. Na Argentina, os grupos e militantes de diretos humanos no país têm dado ênfase na questão da justiça - procurando responsabilizar e punir os agentes do Estado responsáveis pelos crimes e violações cometidos durante a ditadura. A África do Sul tem dado ênfase à memória, à denúncia e revelação dos fatos com o objetivo de promover uma reconciliação nacional. O Brasil tem dado ênfase à questão da reparação. Mas em todos esses processos, no entanto, o testemunho é um elemento vital.

\section{No caso da justiça de transição no Brasil há uma particularidade: centralidade do tema da anistia no processo político brasileiro}

A anistia teve um papel político importante na luta contra a ditadura militar, posteriormente teve um papel político e simbólico na reconstrução democrática, e galvanizou, na discussão sobre a revisão da Lei da Anistia, o tema da responsabilização e punição dos culpados pelos crimes cometidos pela ditadura.

A luta pela anistia, a partir de meados da década de 1970 unificou e mobilizou vários grupos políticos e movimentos sociais. A campanha pela anistia foi a primeira grande campanha política nacional depois do AI-5. O ano de 1977 foi uma data importante nesse processo. Ela marcou um momento de retomada das lutas e manifestações políticas públicas nas principais capitais do país. O estopim foi a prisão de alguns jovens, ligados a organizações de esquerda, que estavam distribuindo panfletos numa comemoração operária do Primeiro de Maio em São Paulo. Com a palavra de ordem "Libertem nossos presos! Agora, já!" estudantes de todo o país realizaram 
amplos atos públicos em várias universidades e, junto com outros setores da oposição, aproveitaram o movimento e criaram o Comitê $1^{\circ}$ de Maio pela Anistia: o primeiro passo para uma campanha pública, de rua e ofensiva pela anistia no país. Logo depois, no início de 1978, foi criado no Rio de Janeiro o Comitê Brasileiro pela Anistia, somando-se a outros comitês que já existiam, como o Comitê Feminino pela Anistia. Na sequência foram criadas sedes do CBA em várias cidades do país.

Nesse momento a atuação dos jornais da imprensa alternativa - como Movimento, Em Tempo, Versus - foi bastante importante. Eles ajudaram a divulgar e ampliar a campanha pela anistia. Com apoio dessa imprensa e de movimentos sociais, o CBA dirigiu uma campanha nacional pela "Anistia ampla, geral e irrestrita”. Esta foi a bandeira de luta e a palavra de ordem que marcou a transição política brasileira.

Mas a anistia que foi promulgada na Lei de Anistia de 1979 não foi a anistia desejada pelos setores mais combativos da sociedade - em especial o CBA. Foi uma anistia parcial, restrita e que, ainda por cima, permitia um certo entendimento de "reciprocidade", ou seja, de proteção para os militares e perpetradores da violência do Estado.

A anistia no Brasil tem, portanto, um caráter complexo, como insiste em dizer o próprio presidente da Comissão de Anistia, sr. Paulo Abrão. Ela representou, por um lado, uma conquista parcial da sociedade e dos grupos que lutavam pela "anistia geral e irrestrita” (e que viram a anistia como resultado, ainda que imperfeito, dessa luta); mas, por outro lado, representou também uma vitória parcial dos militares e da classe dirigente, que aprovou uma anistia limitada e se desobrigou da apuração das responsabilidades e dos crimes cometidos pelo regime.

A Lei de Anistia foi recebida como uma vitória parcial pelos movimentos de oposição ao regime. O verão de 1979 para 1980 entrou para a história como o "verão da anistia"; os exilados voltavam e eram recebidos com festa no aeroporto do Galeão. Por outro lado, as famílias de mortos e desaparecidos políticos nada tinham a comemorar, a lei não aliviava a dor dessas famílias nem tocava na questão das mortes e desaparecimentos forçados. Mas o retorno dos exilados não encerrou a questão da anistia no Brasil. Aos poucos, por medidas e leis complementares, todos os prisioneiros políticos foram libertados, ultrapassando as barreiras inicialmente impostas pela Lei da Anistia de 1979. Nos anos seguintes - em 1985, 1988, 1992, 1995, 2001 e 2002 - a anistia foi alvo de nova legislação federal (Rodeghero; Diestman; 
Trindade, 2011). De um modo geral essas leis visavam ampliar os benefícios e o número de beneficiados pela anistia, procurando reparar a violência praticada pelo Estado brasileiro durante a ditadura. E por esse processo histórico, o termo "anistia", no Brasil, foi paulatinamente se equiparando ao termo "reparação". O governo de Fernando Henrique Cardoso iniciou esse processo de reparação. A ideia era que o cidadão não fosse apenas anistiado dos crimes políticos dos quais era acusado, mas reparado pelo mal sofrido. A Comissão de Anistia, criada em agosto de 2001, junto ao Ministério da Justiça, tinha (e tem) por função reparar, indenizar, reconduzir a postos públicos e a antigos cargos, enfim, exercer o papel de restaurar e compensar os danos provocados pela ditadura militar a perseguidos políticos. O termo anistia ganhou então uma acepção mais ampla, significando, mais do que tudo, reparação. Essa é uma especificidade do processo político brasileiro, do modelo brasileiro de justiça de transição: a ênfase na reparação e a identificação entre "anistia" e "reparação".

Mais recentemente a anistia foi objeto de discussão na sociedade. Movimentos de direitos humanos tentaram anular o efeito perverso da Lei de Anistia (a noção de "reciprocidade") que inibe a apuração e punição dos crimes cometidos pelo Estado durante a ditadura. A Lei da Anistia promulgada em 1979 tem sido invocada para barrar políticas de verdade e justiça no país. Recentemente o Supremo Tribunal Federal entendeu que a lei se aplica também aos agentes do Estado que cometeram os crimes de tortura, assassinato e desaparecimento de presos políticos durante a ditadura militar. Essa interpretação da lei não é aceita por vários setores da sociedade. Recentemente esse debate foi reaberto com a denúncia do Ministério Público feita ao major da reserva Sebastião Curió Rodrigues de Moura, acusado pelo desaparecimento de cinco guerrilheiros do Araguaia, em 1974. OSTF julgará de novo a questão.

\section{Um acervo de história oral da anistia}

Encaramos, portanto, a anistia como uma questão-chave - política e simbólica - para o entendimento do período e para a compreensão das lutas políticas da época, das disputas em torno da memória do período, do

1 Este texto foi escrito e apresentado antes da instalação da Comissão da Verdade. Os trabalhos da Comissão poderão vir a redefinir os termos dessa afirmação. 
processo de transição vivido pelo país, das políticas de reparação que o Brasil vem implementando, das polêmicas surgidas a partir dessas políticas, dos desafios referentes à consolidação democrática e das polêmicas em relação às demandas de verdade e justiça. A partir desse pressuposto começamos a constituir nosso acervo com depoimentos de pessoas que foram perseguidas políticas, familiares de mortos e desaparecidos, militantes de movimentos de direitos humanos, militantes políticos que lutaram contra a ditadura e que participaram da campanha pela anistia. Nosso objetivo é narrar a história política do Brasil recente a partir da chave da anistia e analisar a importância da palavra e do testemunho na superação individual e coletiva de contextos políticos pós-traumáticos.

Elaboramos nossa lista de depoentes não a partir de nomes isolados, mas buscamos grupos de pessoas articuladas em "comunidades de sentido" - grupos de pessoas que integraram uma unidade orgânica: um partido, um movimento, uma organização política, etc. Nos norteou não apenas a noção de comunidade afetiva de Halbwachs (1990) - uma unidade a partir da qual pessoas compartilham e constroem suas memórias, mas também a concepção de Franco Ferrarotti sobre biografias coletivas. Num livro que foi pioneiro nos estudos biográficos, intitulado História e histórias de vida: o método biográfico nas ciências sociais, Ferrarotti (1983) chamou a atenção para a relação entre a história e as múltiplas histórias individuais e a possibilidade que daí decorre de ler uma sociedade através de uma ou muitas biografias.

As entrevistas foram feitas na modalidade de "história de vida", mas acentuando a trajetória política do depoente e enfocando sua militância contra a ditadura, seus embates, a perseguição política sofrida, sua inserção no processo de redemocratização e na justiça de transição implementada no país. Ênfase particular foi dada na relação do depoente com o tema da anistia e da reparação política.

As entrevistas permitem perceber as diferentes construções de memória do período da ditadura militar; as diferentes e conflitantes versões sobre fatos e temas; as disputas pela memória. E as polêmicas em torno do próprio processo de anistia e reparação. Nesse terreno os autores que mais nos ajudaram foram Michel Pollak e Andreas Huyssen.

Michel Pollak (1989) chamou atenção para os processos de dominação e submissão das diferentes versões e memórias, apontando para a clivagem entre a memória oficial e dominante e "memórias subterrâneas", marcadas pelo silêncio, pelo não dito, pelo ressentimento. A essa dimensão conflitiva 
da memória, Huyssen (2005) acrescentou um outro dado: o dinamismo e mutabilidade das versões e dos conflitos, mostrando que a relação entre o que é lembrado e o que é esquecido muda, de acordo com a conjuntura e com as possibilidades e necessidades políticas de uma época.

Temos, portanto, três eixos de investigação e análise de nosso acervo de depoimentos:

1 - Os embates e disputas em torno da memória do período; os temas polêmicos e os tabus, as "memórias subterrâneas".

2 - As experiências de vida relatadas nas entrevistas, que nos permitem conhecer o horizonte de possibilidades, de escolhas, de valores, de caminhos, de projetos, de utopias, de perdas, frustrações e dor de uma época. 3 - O papel do testemunho e da palavra na superação não só individual, mas também social, em contextos posteriores a períodos de violência política.

Seria impossível, neste artigo, dar conta desses três eixos em profundidade. Na verdade, este trabalho é uma primeira aproximação teórica, metodológica e analítica desse acervo de mais de quarenta depoimentos gravados e filmados no Rio de Janeiro, São Paulo e Minas Gerais ao longo do ano de 2011. Pretendemos explorar um pouco esses três eixos, acreditando que com isso estamos abrindo um caminho de análise que poderá ser aprofundado por outros estudos.

\section{1 - As disputas pela memória}

Os depoimentos têm apontado as disputas pela memória do período; questôes controversas, polêmicas e tabus. Entre elas uma das mais marcantes se refere à memória do pré-64, ou seja, do governo de João Goulart e do próprio golpe militar. Existe claramente uma disputa de versões nos depoimentos sobre esse período e esse tema. Para os entrevistados mais idosos, que foram cassados, presos ou exilados em 1964 - como alguns velhos sindicalistas ainda vivos - há uma memória desse período como sendo um momento de glória, o período áureo da democracia brasileira: o movimento sindical, a campanha pelas reformas de base, a atuação da União Nacional dos Estudantes (UNE) e do Centro Popular de Cultura da UNE (CPC). Clodesmidt Riani, ex-presidente da Confederação Geral do Trabalho (CGT), braço direito do presidente João Goulart, principal responsável pelo dispositivo 
sindical e trabalhista do governo, hoje com 93 anos, é um dos principais representantes dessa corrente. Riani foi um dos primeiros cidadãos cassados e presos logo após o golpe. Representava, para os militares, a encarnação viva da ameaça da "república vermelha e sindicalista". Em seu depoimento Riani, descendente de imigrantes italianos, refere-se ao presidente João Goulart de forma elogiosa, carregada de emoção e admiração. Para ele Jango era "próximo dos trabalhadores" e "inteiramente acessível”. Riani lembra que tinha acesso direto aos aposentos do presidente - "homem modesto e simples".

Mas não apenas os sindicalistas; militantes estudantis ligados ao Partido Comunista Brasileiro (PCB) e ao CPC da UNE também enaltecem o momento pré-64 em seus depoimentos. Ferreira Gullart narra as experiências artísticas e a criatividade da geração envolvida com as propostas políticas e artísticas da época.

A historiadora Dulce Pandolfi, que era uma estudante secundarista no início dos anos 1960, em Pernambuco, situa a politização do governo estadual de Miguel Arraes:

[...] eu acho que Pernambuco era o estado mais tenso do Brasil, com a questão do Nordeste em foco, a questão camponesa. Então eu acho que foi um momento muito rico e que eu acho que produziu muitos efeitos em mim: essa preocupação com o social, essa vontade de participar, eu lembro das eleições, das campanhas, como aquilo me mobilizava, assim como o próprio governo Arraes. Imaginam eu andava com um button dele, estudando em um colégio de freiras supertradicional, reacionaríssimo. ${ }^{3}$

Para outros entrevistados, no entanto - sobretudo militantes das organizações da esquerda armada, mais jovens - esse período não é valorizado da mesma forma; ao contrário, muitas vezes é identificado com o adjetivo de populista ou de reformista. Todo um outro segmento da esquerda brasileira após o golpe de 1964 construiu uma memória negativa do governo Goulart e de toda a experiência política do pré-64 - da campanha pelas reformas de base, da atuação do PCB e do presidente. Para este segmento, a experiência

2 Clodesmidt Riani. Depoimento concedido ao projeto "Marcas da Memória: História Oral da Anistia no Brasil” (Equipe do Rio de Janeiro - UFRJ). Juiz de Fora, 28 de setembro de 2011.

3 Dulce Pandolfi. Depoimento concedido ao projeto "Marcas da Memória: História Oral da Anistia no Brasil” (Equipe do Rio de Janeiro - UFRJ). Rio de Janeiro, 25 de maio de 2011. 
do pré-64 teria sido essencialmente reformista e não revolucionária, e teria, por esta direção incorreta, desvirtuado e enfraquecido o movimento popular que lhe dava base política.

Ou seja, uma das principais polêmicas que aparece refere-se à própria história política do país, ao enquadramento da história e da memória do período pré-64 e ao próprio golpe militar.

\section{2 - O relato das experiências de vida: história, memória e retórica}

As experiências que podem ser vividas por uma pessoa são datadas. Um horizonte de possibilidades de escolhas, de caminhos, de vivências concretas é historicamente construído. $\mathrm{O}$ trabalho com biografias e com a história oral nos permite investigar como, concretamente, na vida de algumas pessoas, este horizonte de possibilidades se apresenta. Esta é uma das maneiras de - repetindo a expressão de Ferrarotti (1983) - compreender a história a partir de uma ou múltiplas histórias de vida. A história oral, através da coleta, organização e divulgação de depoimentos muito tem nos ajudado a conhecer a experiência humana em tempos de crise e contextos de violência política.

Mas os relatos de vida de nossos depoentes não colocam em questão apenas a memória, mas também a retórica. Nos depoimentos não existe apenas uma relação entre memória e esquecimento, não se trata apenas de selecionar o que deve ser lembrado e o que deve ser esquecido, mas também como as coisas devem ser contadas ao entrevistador. Ou seja, a retórica é fundamental. Como narrar uma vida de tal forma que ela faça sentido, apesar (ou por causa) das prisões, exílios, torturas, perdas, mortes, etc. Em quase todos os depoimentos existe uma busca de sentido, algo que justifique trajetórias de vida que, algumas vezes, foram inteiramente conturbadas pela perseguição política.

Muitos de nossos depoentes apresentam suas trajetórias de vida como exemplares - seja como exemplo para futuras gerações, seja como exemplo (representação) de sua própria geração. Outros não, outros apresentam essencialmente um relato de dor e de uma vida fragmentada pela repressão política. A diferença entre os primeiros e os segundos é dada, de uma forma geral, pela existência ou não de uma rede social, mas sobretudo política, em torno do depoente. O sobrevivente, como escreveu Primo Levi (1988), é aquele 
que não morreu, que escapou, que não vivenciou o pior. Para ele se aceitar como sobrevivente é necessário uma rede de apoio que justifique, explique e transforme em ação política essa sobrevivência. Dito mais simplesmente: o trauma da violência política é mais facilmente superado quando trabalhado coletivamente no interior de um espaço politicamente investido e com parceiros políticos.

Entre as experiências narradas algumas das mais interessantes para o historiador são aquelas que narram a experiência da vida cotidiana da prisão: a dor, o riso, as vitórias e derrotas, a doença, a organização e vida comunitária na prisão. Nesse sentido, são bastante significativos os depoimentos das mulheres. São particularmente expressivos os depoimentos de mulheres como o de Ana Miranda (Ana Bursztyn), Flávia Schilling, Rose Nogueira, entre outros.

Flávia Schilling exilou-se com sua família logo após o golpe de 1964. Seu pai, Paulo Schilling, político gaúcho ligado a Brizola e Jango, era um dos nomes mais importantes do governo de Goulart. A família exilou-se no Uruguai. Flávia tinha 11 anos. A vida dos exilados adultos está sempre ligada a seu país de origem; mas os exilados crianças e adolescentes ligam-se à vida cotidiana do país que os acolhe. Flávia cursou o liceu uruguaio, envolveu-se com o movimento estudantil desse país e, muito jovem, ingressou na organização guerrilheira dos Tupamaros. Flávia chegou a iniciar o curso de medicina, mas o interrompeu devido à luta política. Em 1972 abandonou a faculdade e entrou na clandestinidade.

A clandestinidade é a tua morte social, é uma situação que até hoje eu não gosto de lembrar, porque é um tempo em que você não vive socialmente, é um tempo em branco, um espaço vazio. É de uma inutilidade, de uma brutalidade... A clandestinidade realmente é um momento terrível, porque você não faz nada, você só se esconde, você não existe... ${ }^{4}$

Flávia foi presa na rua em novembro de 1972. Tentou fugir, correu, o policial atirou em direção à sua nuca. $\mathrm{O}$ tiro pegou no pescoço. Sua primeira prisão foi o hospital militar. Foi operada, salvou-se; mas durante muito tempo as fotos em que aparecia mostravam o curativo e, depois, a cicatriz

4 Flávia Schilling. Depoimento concedido ao projeto "Marcas da Memória: História Oral da Anistia no Brasil” (Equipe do Rio de Janeiro - UFRJ). São Paulo, 18 de julho de 2011. 
no pescoço. Flávia foi libertada no final de 1979, pela ação do Comitê Brasileiro pela Anistia que pressionava o governo brasileiro a pedir ao Uruguai sua extradição. Mas, pouco antes de ser libertada, Flávia viveu uma situação dramática, um tipo de chantagem que só pode ser feita a uma mulher. Diagnosticada com um mioma no útero ela necessitava urgentemente de uma cirurgia, sem a qual poderia perder o órgão. $O$ governo uruguaio exigiu, em troca da cirurgia, que ela desse um depoimento público afirmando que estava em ótimas condições e que era muito bem tratada na prisão.

$\mathrm{Na}$ época eu estava com um mioma no útero, é uma situação dramática, porque eu já tinha 25 anos, óbvio que eu queria sair e ter filho. Eles me chantagearam no sentido de que essa cirurgia seria feita se eu desse um depoimento, porque já havia pressão no Brasil. [...] Mas é impossível você dizer que está ótima quando está pesando 50 quilos, e aquela cara, a gente usava uniforme, cabelo cortado muito curto, enfim, você não está ótima. ${ }^{5}$

Flávia foi libertada, voltou ao Brasil, engajou-se no Partido dos Trabalhadores, cursou a faculdade de educação, fez mestrado, casou-se e teve um filho, hoje com 20 anos. É professora de Educação na Universidade de São Paulo (USP) e estuda a questão da violência nas escolas.

Mas na prisão, a violência contra a mulher é, quase sempre, o estupro. Um dos depoimentos mais fortes que temos de denúncia da violência sexual contra mulheres presas é o da jornalista Rose Nogueira. Rose foi presa em São Paulo, em 1969, com 23 anos. Era militante da Ação Libertadora Nacional (ALN). Tinha acabado de ter um bebê, que tinha apenas um mês de vida e que ficou aos cuidados de seus sogros. Quando foi presa, Rose estava amamentando. Ficou presa por quase um ano, sendo torturada seguidamente, uma tortura marcada pela violência sexual. Mas em sua memória do episódio, a violência dos perpetradores se transforma em fraqueza:

Eu era moça, era bonitinha, como todas, e eles me chamavam de Miss Brasil. Lá tinha um sujeito, que era um tarado, que não podia me ver. Quando ele me via, fazia assim [gesto esfregando as mãos]. O nome dele era Traly, o sobrenome, chamavam de Traly. [...] Eu tinha leite, e ele dizia que o leite atrapalhava o desejo dele. Então, mandou me dar uma injeção para cortar o 
leite. [...] Tinha um tal de Nelsinho também. E era tudo "inho", Nelsinho, Rubinho, Luizinho, Toninho, era tudo "inho", todos no diminutivo, porque eles eram menores mesmo. Eram menores! ${ }^{6}$

\section{A vida na prisão: a construção do cotidiano}

Um dos aspectos mais interessantes que podem ser observados nos depoimentos refere-se à vida cotidiana na prisão. Para enfrentar o dia a dia da vida na prisão uma série de estratégias eram montadas. A principal delas era constituir uma rotina que conferisse uniformidade e sentido ao cotidiano, para que as horas passassem de acordo com uma certa regularidade.

Flávia Schilling, presa no Uruguai, diz que duas coisas a ajudaram na prisão: a literatura e a prática da ioga.

Eu lia dois/três livros por semana, a literatura foi a minha grande aliada. Eu acho isso muito interessante porque no Uruguai eles nunca tiveram coragem de proibir a leitura, eu acho que exatamente por que é um país tão escolarizado, é uma coisa tão importante a educação, que acho que eles não tiveram coragem de cortar isso, então mesmo nos piores quartéis, os livros entravam. ${ }^{7}$

Na prisão, segundo Flávia, todo esforço era no sentido de preservar a dignidade e a saúde:

Eu tinha uma rotina de tentativa de saúde, a gente tinha uma hora de banho de sol, às vezes duas, uma de manhã, outra de tarde, e caminhar, caminhar erguida, caminhar com energia, entendeu? Caminhar olhando para longe. ${ }^{8}$

Até que apareceu a ioga.

6 Rose Nogueira. Depoimento concedido ao projeto "Marcas da Memória: História Oral da Anistia no Brasil” (Equipe do Rio de Janeiro - UFRJ). Rio de Janeiro, 27 de janeiro de 2012.

7 Depoimento de Flávia Schilling.

8 Depoimento de Flávia Schilling. 
Meus pais me mandaram um livro de ioga, imagina um livro de ioga, né? E eu lá decifrando as posições, eu fazia ioga mais de uma hora de manhã, mais uma de tarde. A questão da respiração foi fantástica para mim. ${ }^{9}$

\section{Falar da dor}

Uma das maiores dificuldades no exercício da história oral é falar da dor. Inegavelmente, falar da dor, denunciar a violência perpetrada contra pessoas sem condições de defesa, relatar abusos para que sejam punidos ou coibidos tem sido um elemento mobilizador da história oral. Com esse intuito pesquisadores recolheram depoimentos de vitimas do Holocausto, de campos de concentração, de guerras civis e de regimes ditatoriais. Mas lidar com a dor é sempre difícil, tanto para quem fala como para quem escuta. Para o depoente, narrar o sofrimento, às vezes, é extremamente difícil. Não apenas porque o faz reviver momentos dolorosos, lembranças que muitas vezes querem ficar esquecidas, mas também porque o coloca num duro dilema sobre si próprio. Como narrar essa dor? De que ângulo? Como vítima, como herói, como sobrevivente? A narrativa da dor é um processo complexo para a maior parte dos depoentes que relatam violências e sevícias. Para o pesquisador também é difícil. Uma dificuldade que se apresenta em vários níveis: como perguntar? Como escutar? Como incorporar o relato da dor numa narrativa histórica? Essa questão foi desenvolvida por Dominick LaCapra no livro Writing history, writing trauma, ${ }^{10}$ uma discussão teórica sobre a possibilidade de uma narrativa sobre o Holocausto reunindo história, filosofia e psicanálise (LaCapra, 2005). LaCapra (2005. p. 105) comenta o papel que assumiram os testemunhos pós traumáticos e a especificidade do aporte que eles trazem: "La importancia de los testimonios se hace más evidente cuando se piensa en que aportan algo que no es idéntico al conocimiento puramente documental." Mas LaCapra reconhece a dificuldade do exercício do historiador frente àqueles que dão o seu testemunho, ou seja, frente às vítimas e aos sobreviventes. Para LaCapra o historiador que trabalha com testemunhos converte-se, ele próprio, numa testemunha secundária (testigo secundário), porque tem acesso,

9 Depoimento de Flávia Schilling.

10 Como o livro não foi traduzido no Brasil utilizamos a edição argentina Escribir la historia, escribir el trauma, lançado pela editora Nueva Visión em 2005. 
em primeira mão, a um relato/registro do passado que só pode ser conhecido através daquele testemunho que, de certa forma, revive os acontecimentos traumáticos que relata. Essa narrativa dos acontecimentos traumáticos, para ele, é a parte mais difícil do trabalho com testemunhos. E LaCapra (2005, p. 115) coloca a necessidade de uma ética própria para lidar com essa questão:

Cabe preguntarse si se puede y se debe desarrollar lo que podría llamarse una ética de la respuesta para los testigos secundarios: entrevistadores, historiadores que hacen historia oral y comentaristas. Tal ética podría operar como fuerza o factor dentro de un campo de fuerzas más amplio. Es importante reconocer que el historiador o cualquier otro académico, por atento y empático que sea, no puede asumir la voz de la víctima. Además, en su calidad de tal, el académico no es un terapeuta que trabaja en estrecha relación con los sobrevivientes u otras víctimas del trauma y no tiene derecho a identificarse con ellos.

É difícil, portanto, a posição do historiador. Sua empatia com as testemunhas não pode se transformar em identificação. Para LaCapra, a postura ética do historiador seria, essencialmente, a de reconhecer a alteridade do outro, dar espaço para a singularidade de sua experiência traumática. Mas, mesmo isso, para LaCapra, pode ser problemático. Ele se questiona sobre o direito do historiador de perguntar sobre a dor e, com isso, reviver e atualizar essa dor:

[...] con respecto a los que hacen entrevistas o historia oral, se puede decir que tratar de inducir al sobreviviente a vivir nuevamente el trauma y volver a ser víctima en cierto sentido, delante de las cámaras, es una actitud ambigua, aun cuando el móvil sea la empatía o el intento de identificarse plenamente con la víctima para transmitir su experiencia al espectador. (LaCapra, 2005, p. 116).

O questionamento de LaCapra cala fundo em todos aqueles que trabalham com história oral e com testemunhos. Qual é o limite da "intervenção" do pesquisador? Como trabalhar com o testemunho pós-traumático sem "explorar" a dor, sem reificar o sofrimento, escapando da vitimização e da heroicização do depoente, respeitando sua alteridade, sua singularidade e, mais do que tudo, o seu desejo de narrar, não indo além dele? Na realização das entrevistas desse acervo várias vezes nos deparamos com essas questões. Alguns depoentes falam da dor, outros não. E o fazem de formas diferentes. 
Ana Miranda Batista (Ana Bursztyn na época de sua prisão), integrante do Fórum de Reparação e Memória, em seu depoimento relata algumas de suas experiências dolorosas. Ana, filha de imigrantes judeus poloneses que vieram para o Brasil antes da Segunda Guerra, quando veio uma grande massa de judeus da Europa por volta de 1930, cresceu num ambiente, como ela mesmo define, "socialista e humanista", e desde adolescente participava de círculos de discussão e debate de judeus comunistas. Em 1967, já na faculdade, cursando farmácia, entrou em contato com organizações de esquerda que criticavam o PCB. Em 1969 Ana entrou para a ALN. Em julho de 1970 foi presa. Em seu depoimento Ana faz revelações surpreendentes sobre as modalidades de tortura.

A mais extravagante (também mencionada em outros depoimentos) é a utilização de um jacaré para intimidar o preso.

Às vezes não te dão porrada, mas põem um jacaré em cima de você. Um jacaré! Não muito grande, disseram eles depois que era desdentado. É assim, se perguntar, ele vai dizer: "Tortura, não. Foi só um choquinho. Ah! O jacaré não fazia nada!” Eles minimizam, entendeu? Eles colocavam o jacaré em cima e para cada um tinha um nome! O meu jacaré era Marighela! ${ }^{11}$

Maria José Nahas, a Zezé, militante da organização armada Comando de Libertação Nacional (Colina), também enfatiza o sofrimento do isolamento. Zezé foi presa como uma das "louras da metralhadora". As militantes envolvidas em ações armadas costumavam usar uma peruca loura para não serem identificadas. Em São Paulo, no Rio de Janeiro e em Belo Horizonte circulavam diferentes "louras" armadas de metralhadoras. Zezé era uma delas. A jovem de Muriaé, Zona da Mata mineira, veio para a capital em 1966 para cursar a Escola de Medicina; dois anos depois, já militava no Colina. Presa como a "loura da metralhadora", ficou na solitária por cinco meses.

Eu sempre ficava isolada. Na cela de castigo, na surda da penitenciária, eu fiquei cinco meses ali, isolada. Cinco meses completamente isolada. Só saía dali para fazer depoimento. O próprio diretor da penitenciária falou: "Não, ela aguenta isso! Ela teve treinamento em Cuba.” Aí começa a fantasia.

11 Ana Miranda Batista. Depoimento concedido ao projeto "Marcas da Memória: História Oral da Anistia no Brasil” (Equipe Rio de Janeiro - UFRJ). Rio de Janeiro, 7 de julho de 2011. 
Porque ainda não tinha acontecido isso, uma pessoa ficar cinco meses lá e não enlouquecer, né?! Mas quando você tem certeza daquilo que você está fazendo, você encontra mecanismos de defesa. É incrível como você mobiliza força que você não sabe que tem! $!^{12}$

A experiência da dor, para ser suportada, tem que adquirir algum sentido. A narrativa de Ivan Seixas é um exemplo disso. Filho de pais operários e comunistas, Ivan muito cedo começou a atuar politicamente. Em 1971 ele e seu pai, Joaquim Seixas, foram presos pela Operação Bandeirantes (Oban). Eram militantes do Movimento Revolucionário Tiradentes. Ivan tinha 16 anos. Pai e filho foram torturados um na frente do outro - para que a dor de um fizesse o outro falar. Joaquim Seixas foi morto na prisão. Quando nos narra essa experiência-limite de dor, Ivan a apresenta como um pacto firmado entre ele e seu pai. Narrando a prisão, ele conta:

Ao chegar na Oban nós fomos tirados do carro no pátio [...] Começou uma pancadaria e eu e meu pai, presos por uma algema única, os dois pulsos, nós tínhamos como uma decisão nossa que era "nós não vamos apanhar, nós não vamos falar, mas vamos brigar", aí começou o espancamento e nós brigamos com eles, apesar de estarmos algemados foi uma troca de coronhada, com soco, pontapé, mas foi tão violento o espancamento porque a gente deu o azar desgraçado de ser capturado na hora que os caras estão trocando plantão. Então tinha um bando deles que tava saindo e um bando deles que tava entrando pra plantão. ${ }^{13}$

Para Ivan era importante mostrar para o pai que ele não fraquejara, que ele estava enfrentando com coragem a situação. Mas Ivan afirma também, em seu depoimento, que não se pode ter ilusões sobre esse enfrentamento.

Porque na tortura, uma coisa muito importante de dizer, não tem valente, não tem covarde. Tem o bom e o mau administrador do medo, porque o medo todo mundo sente. Ninguém tá preparado pra ser torturado,

12 Maria José Nahas (Zezé). Depoimento concedido ao projeto "Marcas da Memória: História Oral da Anistia no Brasil” (Equipe do Rio de Janeiro - UFRJ). Belo Horizonte, 27 de novembro de 2011.

13 Ivan Seixas. Depoimento concedido ao projeto "Marcas da Memória: História Oral da Anistia no Brasil” (Equipe do Rio de Janeiro - UFRJ). São Paulo, 27 de janeiro de 2012 
ninguém tem controle absoluto. O que tem é controle do medo, então se eu tenho um bom controle do medo, eu percebo que eu tenho a informação. Eles podem me matar, mas se eles me matarem eles perdem a fonte que, possivelmente, vá fornecer informação. É um jogo que você tem que, minimamente, dominar. Você tem que entender que isso daí é o seu capital. ${ }^{14}$

Ivan atualmente é um dos membros mais destacados da Comissão de Familiares de Mortos e Desaparecidos.

\section{Falar do riso}

Mas em vários depoimentos existe o relato de inúmeros episódios engraçados, casos que são narrados ressaltando a parte cômica ou jocosa. Os casos engraçados estabelecem uma imediata cumplicidade entre o depoente e a equipe entrevistadora. Mais do que isso: a narração de episódios cômicos retira o depoente da condição de vítima e o reintegra na humanidade. $\mathrm{O}$ riso é sempre uma atividade compartilhada, um elo de ligação. Nesse sentido, o relato cômico aproxima não apenas depoente e entrevistador mas também o aproxima dos futuros leitores/ouvintes daquele depoimento. $\mathrm{O}$ riso arranca o depoente de sua condição isolada e o devolve ao seio da comunidade, ao conjunto das pessoas que riem porque entendem e compartilham uma piada. $\mathrm{O}$ filósofo, linguista e crítico literário Mikail Bakhtin (2010) foi um dos precursores em evidenciar essa dimensão de signo agregador do riso em seu estudo sobre a cultura popular medieval e renascentista.

Muitos de nossos depoentes são narradores de histórias engraçadas. Os momentos em que narram essas histórias são os momentos em que depoente e entrevistadores "relaxam" e riem juntos de uma comicidade compartilhada. Nessas narrações os depoentes também mostram como que uma vitória sobre a violência: afinal, não têm apenas duras lembranças, marcas de sofrimento, mas também lembranças engraçadas, são capazes de rir do que passou. Essa narração cômica representa, de certa forma, uma vitória sobre a dor e o trauma.

Podemos ver alguns exemplos desses casos cômicos. Alguns dos mais engraçados são relatados por Maria José Nahas, a Zezé, como a história do enxoval que se transformou em arsenal (armas e munições):

14 Depoimento de Ivan Seixas. 
Quando a gente estava ali formando o comando armado, a gente tinha que ter armas e estávamos com dificuldade de ter armas [...] a gente tinha um contato, um desses contrabandistas de armas que tem até hoje, mas e o dinheiro? Então eu decidi casar, e disse: "Mamãe, acho que vou casar!", "Mas como? Te pediram em casamento?" Eu disse "Não! Não pediu não, mas eu acho que vou pedir! Você tem que me dar o dinheiro para eu fazer o meu enxoval". [...] e o fato é que eu recebi esse dinheiro para fazer o enxoval, e entreguei para o Ângelo que era o nosso comandante. Cheguei para ele e falei: "Olha, eu consegui o dinheiro para fazer o enxoval." E ele disse: "Nossa, que maravilha, nós estamos precisando demais desse dinheiro." Algum tempo depois, ele chegou lá em casa, e falou: "Olha, chegou o seu enxoval." [...] O meu enxoval rendeu, sabe? Eles conseguiram metralhadora, daquela que aparecia em filmes da máfia, eles gostavam de usar essa metralhadora. E falava: "Olha, gostou dos seus lençóis? Você acha que seus lençóis são bons?” E todo o armamento que a gente teve estava ali, depois nós não conseguimos mais armamentos. ${ }^{15}$

Vejamos agora o nosso último eixo de análise.

\section{3 - A força da palavra}

Eu gostaria ainda de destacar neste trabalho um aspecto do processo de anistia e reparação que o Brasil tem vivido nos últimos anos, a partir das "Caravanas de Anistia". Como já foi salientado no início deste texto, a justiça de transição no Brasil tem dado ênfase à questão da reparação. O objetivo principal é reparar o dano cometido pelo Estado. Com esse espírito a Comissão da Anistia tem passado por vários estados do Brasil realizando audiências públicas em que são julgados diferentes processos de anistia. Esse procedimento é chamado de "Caravana da Anistia". Nos julgamentos a peça-chave é o processo encaminhado à Comissão de Anistia, é baseada nele que a comissão toma a sua decisão. Mas os momentos mais importantes da solenidade são ligados à palavra: o primeiro é o depoimento do requerente à anistia. Por dez minutos a tribuna é dele, pode falar o que quiser, revelar, denunciar, aclamar. E, após o julgamento, se deferido, o presidente da Comissão de Anistia

15 Depoimento de Maria José Nahas (Zezé). 
pede perdão, em nome do Estado brasileiro, pelos danos cometidos ao requerente durante a ditadura militar. Todos os nossos depoentes que foram anistiados e passaram por este ritual falam desse pedido de perdão oficial. Para todos eles o pedido de perdão do Estado é o elemento chave da reparação. Recorro mais uma vez ao depoimento de Dulce Pandolfi. Dulce foi presa em agosto de 1979 devido à sua ligação com a ALN e permaneceu presa por um ano e meio, passando pelas dependências da Polícia do Exército (PE), do DOPS, do presídio Talavera Bruce e, em Recife, pelo presídio Bom Pastor. Seu depoimento é um dos que relata com maior detalhe, franqueza e coragem as torturas e sevícias a que foi submetida. Ao final de seu depoimento ela destaca a importância do pedido oficial de perdão pelo Estado:

O Estado está agora diante de mim se curvando e me tratando desse jeito, que coisa linda! [...], foi quando eu desabei, eu me senti muito recompensada, foi uma coisa muito bonita! Mesmo que a gente saiba que, claro, não apagou as coisas do passado, mas você sente que finalmente a cidadania chegou nesse país. Acho mesmo que todo mundo deveria entrar [com o pedido de reparação]. Foi um momento muito lindo da minha trajetória. ${ }^{16}$

\section{Algumas conclusões}

No contexto recente da América Latina os historiadores que trabalham com história oral, com depoimentos, têm tido grande atuação. Eles têm ajudado a recompor e a problematizar a história e a memória dos períodos ditatoriais. Têm organizado acervos de depoimentos, divulgado fatos e episódios obscuros, têm trazido à luz diferentes experiências e ajudado a reparar injustiças. A história oral está tendo um papel efetivo na transição democrática vivida na América Latina. Historiadores têm estado ao lado de militantes de direitos humanos, de ativistas políticos, de juristas, de pessoas que foram vítimas de arbítrios e perseguições políticas - registrando, entrevistando, coletando depoimentos e impressões, organizando acervos, divulgando, recompondo memórias, problematizando memórias. Mas é bom lembrarmos que, ao lidar com depoimentos, o historiador deve se precaver contra a "sedução"

16 Depoimento de Dulce Pandolfi. 
do testemunho e deve procurar sempre exercer a crítica sobre suas fontes. A história oral deve fugir do terreno da pura exaltação da subjetividade; procurando não se "colar" à fala do depoente, não ser subjugada por uma "verdade absoluta” (imaginária), da fala na primeira pessoa. Deve ser capaz, por mais difícil que seja, principalmente nos depoimentos que se referem a momentos de grande violência política, de exercer a crítica e a reflexão.

Enfrentar este desafio é hoje uma questão ética e política na ordem do dia para muitos historiadores, sobretudo na América Latina, em que muitos países vivem seu complexo, contraditório e vital processo de consolidação democrática.

\section{Referências}

ARAUJO. M. P. Uma história oral da anistia: memória, testemunho e superação. In: MONTENEGRO, A.; RODEGHERO, C.; ARAUJO, M. P. (Org.). Marcas da memória: história oral da anistia no Brasil. Recife: Ed. UFPE, 2012. No prelo.

BAKHTIN, M. Culturapopular na Idade Média e no Renascimento. São Paulo: Hucitec, 2010.

BRITO, A. B. de. Verdad, justicia y memoria en Cono Sur. In: BRITO, A. B. de; AGUILAR FERNÁNDEZ, P.; GONZÁLEZ ENRIQUEZ, C. (Ed.). Las politicas hacia el pasado: juicios, depuraciones, perdón y olvido en las nuevas democracias. Madrid: Istmo, 2002. p. 195-245.

FERRAROTTI, F. Histoire et histoires de vie: la méthode biographique dans les sciences sociales. Paris: Librairie des Meridiens, 1983.

HALBWACHS, M. A memória coletiva. São Paulo: Vértice, 1990.

HUYSSEN, A. Resistência à memória: os usos e abusos do esquecimento público. In: BRAGANÇA, A.; MOREIRA, S. V. Comunicação, acontecimento e memória. São Paulo: Intercom, 2005. p. 5-20.

LACAPRA, D. Escribir la historia, escribir el trauma. Buenos Aires: Nueva Visión, 2005.

LEVI, P. É isto um homem? Rio de Janeiro: Rocco, 1988.

POLLAK, M. Memória, esquecimento e silêncio. Estudos Históricos, v. 2, n. 3, p. 3-15, 1989.

RODEGHERO, C.; DIESTMAN, G.; TRINDADE, T. Anistia ampla, geral e irrestrita: história de uma luta inconclusa. Santa Cruz do Sul: EDUNISC, 2011. 
Resumo: Na América Latina, nas últimas décadas, inúmeros países viveram diferentes processos de transição política, passando de ditaduras militares para regimes democráticos. Em todos esses países uma questão tem se colocado para a sociedade e para o Estado: o que fazer com a herança autoritária? Como olhar para esse passado, enquadrá-lo aos novos tempos, tratar as feridas, suprimir o legado da violência? Em todos esses processos de transição política um elemento tem se afigurado como fundamental: a palavra. Revelar os fatos, tornar pública as violações, denunciar as arbitrariedades, resgatar a memória de lutas e resistências tem tido enorme papel simbólico e político na construção de um novo pacto nas sociedades pós-conflitos. A história oral lida com depoimentos, memória, histórias de vida, e por isso mesmo tem tido destacado papel nesse processo. Este texto faz uma reflexão sobre essa relação entre história oral, memória e política, a partir do papel do testemunho e da palavra no processo de superação de contextos de violência política. Abordo aqui algumas questões relativas à Argentina e África do Sul, mas o foco maior é o Brasil e a Comissão de Anistia do Ministério da Justiça, com foi desenvolvida uma pareceria de pesquisa, através do projeto "Marcas da Memória: História Oral da Anistia no Brasil".

Palavras-chave: ditadura, memória, justiça de transição, anistia.

\title{
Oral history, memory and reparation: the role of witness to overcome contexts of political violence
}

\begin{abstract}
In recent decades many countries in Latin America have experienced different processes of political transition from military dictatorships to democracies. In all these countries a question has placed for society and the government: what to do with the authoritarian heritage? How to face this past, how to talk about it and what to do in order to remove the legacy of violence? In all these processes of political transition one element was seen as crucial: the witness. Reveal the facts, publicizes violations, denounce the arbitrary, rescue the memory of struggle and resistance - have had enormous symbolic and political role in the construction of a new covenant in post-conflict societies. Oral History deals with testimony, memory, life histories, and therefore has had a prominent role in this process. This paper intends to reflect on the relationship between oral history, memory, speech and politics, from the study of political transitions experienced in Argentina, South Africa and Brazil. Despite the comparative approach, our major focus is Brazil and the Amnesty Commission of the Ministry of Justice with whom we develop a partnership through the research project "Marks of Memory: Oral History of the amnesty in Brazil".
\end{abstract}

Keywords: dictatorship, memory, transitional justice, amnesty.

Recebido em 23/09/2012

Aprovado em 02/11/2012 